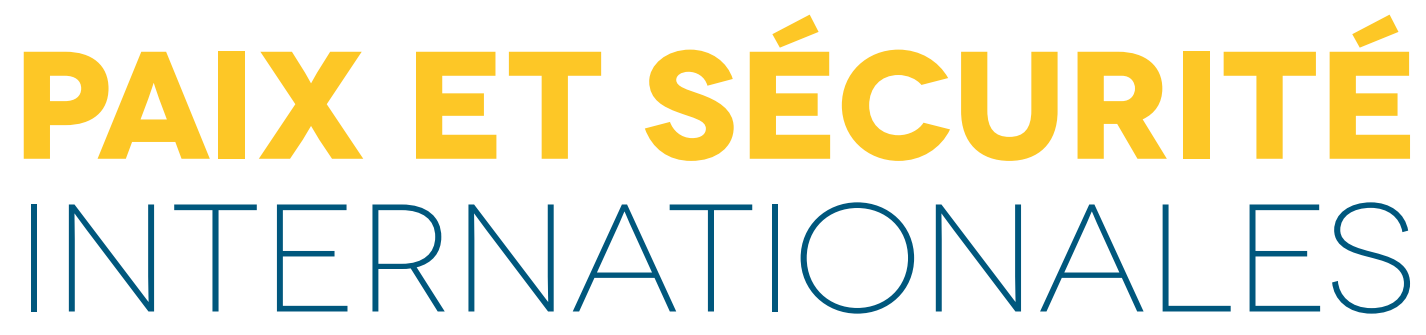

\title{
01
}

2013

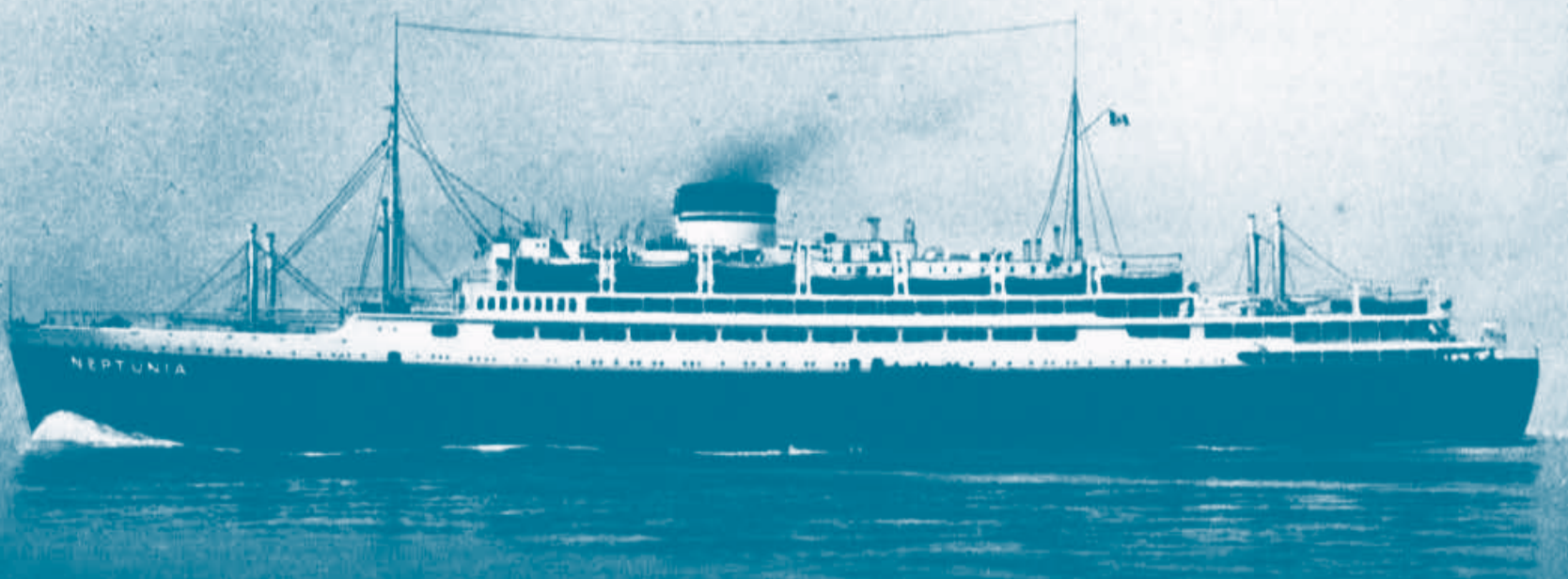

REVUE MAROCO-ESPAGNOLE DE DROIT INTERNATIONAL ET RELATIONS INTERNATIONALES

(NOUVELLE ÉPOQUE) 


\title{
IRREGULAR MIGRATION ACROSS THE MEDITERRANEAN SEA: PROBLEMATIC ISSUES CONCERNING THE INTERNATIONAL RULES ON SAFEGUARD OF LIFE AT SEA ${ }^{1}$
}

Marcello Di Filippo ${ }^{2}$

\begin{abstract}
I.- THE PECULIAR ISSUES RAISED BY IRREGULAR MIGRATION BY
SEA. II.- OBLIGATIONS AIMED AT SAFEGUARDING LIFE AT SEA:

THE RELEVANT TREATY RULES III.- EU LAW AND SAR MATTERS. IV.- CONTROVERSIAL ISSUES, WITH SPECIAL REGARD TO THE MEDITERRANEAN SEA. V.- THE FAILED ATTEMPT OF IMO AND EU TO ELABORATE NEW LEGAL STANDARDS. VI.- NEW APPROACHES CURRENTLY UNDER STUDY BY THE IMO: TOWARDS A REGIONAL TREATY FOR THE MEDITERRANEAN SEA? VII.- FINAL REMARKS. ADDENDUM
\end{abstract}

\section{IRREGULAR MIGRATION ACROSS THE MEDITERRANEAN SEA: PROBLEMATIC ISSUES CONCERNING THE INTERNATIONAL RULES ON SAFEGUARD OF LIFE AT SEA}

\begin{abstract}
Migration by sea is a phenomenon which is largely associated with irregular flows and growing concern by destination States about border control and integrity of restrictive migration policies. Only incidentally, the human rights' costs are extensively debated. The Mediterranean Sea is a crucial scenario which highlights the difficulty encountered by the Search and Rescue regime to cope with the techniques adopted by smugglers and with the additional tensions provoked by some features of EU migration law. The SAR provisions are inherently accompanied by certain elasticity, in order to take into account the variety of concrete situations. In a regional context characterized by political divergences among European states and between the latters and transit countries, some IMO and EU's attempts to draw a solution are evaluated: it clearly emerges that the failures to find out a reasonable compromise are due to factors external to maritime law. Such factors must be addressed with more courage by the EU member states: the hot issue of the burden sharing; a really comprehensive dialogue with origin countries and transit countries on the complex subject of international migration; the renunciation to ask the cooperation of states with a negative human rights record. Absent a more far reaching policy, dramatic events and hidden deaths will sadly continue, as far as the crocodile tears of European politicians when some incident eventually reaches the attention of media and of public opinion.
\end{abstract}

KEYWORDS: irregular migration; maritime law; Search and Rescue regime; IMO; EU; burden sharing; human rights; international cooperation.

1 This article is a revised and updated version of an earlier paper from the same author, whose references are the following: "Irregular Migration and Safeguard of Life at Sea: International Rules and Recent Developments in The Mediterranean Sea", in DEL VECCHIO, A. (ed.), International Law of the Sea: Current Trends and Controversial Issues, Eleven International Publishing, The Hague, forthcoming 2013.

2 Associate Professor of International Law (Full Professor), University of Pisa (marcello.difilippo@sp.unipi. it). 


\section{MIGRACIÓN IRREGULAR EN EL MAR MEDITERRÁNEO: ASPECTOS PROBLEMATICOS RELATIVOS A LAS REGLAS INTERNACIONALES SOBRE LA PROTECCIÓN DE LA VIDA EN MAR}

RESUMEN: La migración vía mar es un fenómeno abundantemente asociado con los flujos irregulares y con la creciente preocupación por parte de los Estados de destino con respecto al control des sus fronteras y a la integridad de sus políticas migratorias restrictivas. Muy raramente, los aspectos relativos a los derechos humanos reciben la atención que merecerían. El Mar Mediterráneo representa un escenario crucial que destaca las dificultades que el régimen de búsqueda y rescate encuentra al enfrentarse con las técnicas empleadas por los traficantes y con las tensiones adicionales consecuencia de ciertas pautas del derecho de inmigración de la UE. Las disposiciones sobre las actividades SAR son inherentemente acompañadas por una cierta elasticidad, a fin de tomar en cuenta la variedad de las situaciones concretas. En un contexto regional caracterizado por divergencias políticas entre los Estados miembros de la UE y entre estos y los Estados de tránsito, algunas tentativas impulsadas por la OMI y la UE son evaluadas en el presente estudio: resulta que el fracaso en llegar a un razonable compromiso se debe a motivos ajenos al derecho marítimo. Tales factores deben ser abarcados con mas implicación por parte de los Estados miembros de la UE: el delicado tema de la repartición de las cargas; una diálogo realmente amplio con los países de origen y con los de tránsito sobre las complejidades de las migraciones internacionales; la renuncia, al mismo tiempo, a pedir la cooperación de países que no respetan con suficiencia los derechos humanos. A falta de una política más ambiciosa y de largo plazo, los eventos dramáticos y las muertes silenciosas están destinados a seguir, así como las "lagrimas de cocodrilo" de los políticos europeos que surgen cuando algún incidente llega a provocar la atención de los medios de comunicación y de la opinión publica.

PALABRAS CLAVES: migración irregular; derecho marítimo; régimen de búsqueda y rescate; OMI; UE; distribución de las cargas; derechos humanos; cooperación internacional.

\section{MIGRATION IRREGULIERE DANS LA MER MEDITERRANEE: ASPECTS PROBLEMATIQUES CONCERNANT LES RĖGLES INTERNATIONALES SUR SAUVEGARDE DE VIE EN MER}

RESUMÉ: la migration via mer est un phénomène qui est en grande partie associé aux flux irréguliers et à la préoccupation croissante des États de destination relativement au contrôle de ses frontières et à l'intégrité de ses politiques migratoires restrictives. Très rarement, les aspects relatifs aux droits de l'homme reçoivent l'attention qu'ils mériteraient. La Méditerranée est un scénario crucial qui met en évidence les difficultés rencontrées par le système de la Recherche et du Sauvetage quand il fait face aux techniques adoptées par les trafiquants et aux tensions additionnelles provoqués par certaines règles du droit d'immigration de l'UE. Les dispositions sur les activités SAR sont accompagnées par certaine élasticité, afin de prendre en compte la variété des situations concrètes. Dans un contexte régional caractérisé par des divergences politiques entre les États membres de l'UE et entre ceux-ci et les États de transit, quelques tentatives poussées par l'OMI et l'UE sont évaluées dans la présente étude : de toute évidence, il ressort que les échecs pour trouver un compromis raisonnable sont dus à des facteurs externes au droit maritime. Ces facteurs doivent être recouverts d'une plus grande participation des États membres de l'UE : la question sensible du partage de la charge, un très large dialogue avec les pays d'origine et de transit sur les complexités de la migration internationale;,le renoncement, au même temps, la demande de coopération des pays qui ne respectent pas suffisamment 
les droits de l'homme. Á l'absence d'une politique plus ambitieuse et à long terme, les événements dramatiques et morts silencieuses vont se poursuivre, et aussi les «larmes de crocodile» des politiciens européens qui se posent lorsqu'un incident vient à provoquer l'attention des médias communication et l'opinion publique.

MOTS CLÉS: migration irrégulière, droit maritime, système de Recherche et Sauvetage, OMI, UE, distribution des charges, droits de l'homme, coopération internationale.

\section{THE PECULIAR ISSUES RAISED BY IRREGULAR MIGRATION BY SEA}

In recent years, migration flows by sea across the Mediterranean and towards southern European Union (EU) Member States have increased significantly. ${ }^{3}$ Contrast actions by coastal states, either unilateral or coordinated through the Frontex agency, and the relevance of international rules concerning various subjects - law of the sea, safeguard of life at sea, human rights, non-refoulement of persons in need of international protection - raise a set of problematic issues. ${ }^{4}$ Recently, the main international organizations dealt with irregular migration and the need to contrast it, underlining alternatively the related threat to security (together with terrorism and organized crime $)^{5}$ or the need to conciliate control of borders and migration policy choices with respect to aliens' human rights and other international provisions. ${ }^{6}$

\footnotetext{
${ }^{3}$ See (with further references) HINRICHS, X. "Measures Against Smuggling of Migrants at Sea: A Law of the Sea Related Perspective', Revue belge de droit international, Vol. 36, 2003, p. 413, at pp. 413-414, 421, 446-447; SPIJKERBOER, T., Trends in the Different Legislations of the Member States Concerning Asylum in the EU: The Human Costs of Border Control, study prepared on behalf of the Commission 'Civil Liberties, Justice and Home Affairs' of the European Parliament, July 2006, Doc. IPOL/C/LIBE/FWC/2005-23-SC1, PE 378.25, at pp. 1-2; United Nations Office on Drugs and Crime, Organized Crime and Irregular Migration From Africa to Europe, July $2006<$ www.unodc.org/pdf/research/Migration_Africa.pdf $>$; COSLOVI, L., Brevi note sull'immigrazione via mare in Italia e Spagna, January $2007<$ www.cespi.it/PDF/mig-mare.pdf>; DE HAAS, H., The Myth of Invasion. Irregular Migration From West Africa to the Maghreb and the European Union, IMI research report, University of Oxford, October 2007; WEINZIERL, R., LISSON, U., Border Management and Human Rights. A Study of EU Law and the Law of the Sea, German Institute for Human Rights, December 2007 $<$ www.institut-fuer-menschenrechte.de $>$, at p. 18.

${ }^{4}$ In this perspective, the European Commission admitted in 2006 the need to carry out an in-depth legal and technical analysis: see the Communication 'Reinforcing the Management of the European Union's Southern Maritime Borders', Doc. COM (2006) 733, 30 November 2006; the subsequent Commission Staff Working Document 'Study on the International Law Instruments in Relation to Illegal Immigration by Sea', Doc. SEC (2007) 691, 15 May 2007 (hereinafter, the Commission Working Document).

${ }^{5}$ See the Berlin Declaration, signed on 25 March 2007 by the Presidency of the Council, the President of the Commission, the President of the European Parliament, on conclusion of the informal meeting of the Heads of State or Government, held in Berlin on 24 and 25 March 2007: see point II, where the undersigned undertake to jointly fight against "terrorism, organized crime and illegal immigration."

${ }^{6}$ See the amendments to the SOLAS and SAR Conventions, approved in 2004 by the International Maritime Organization (hereinafter, IMO), about which see infra, § 4; the UN GA Resolution of 23 February 2007, Doc. A/ RES/61/165, entitled "Protection of Migrants", in particular $\$ \S 6-7$. See also the leaflet, co-authored in 2006 by IMO and the UN High Commissioner for Refugees (hereinafter, IMO \& UNHCR), entitled Rescue at Sea. A Guide to Principles and Practice as Applied to Migrants and Refugees, at <www.unhcr.org/publ/PUBL/450037d34. pdf $>$. More recently, see the accurate study published by the European Union Agency for Fundamental Rights (FRA), Fundamental rights at Europe's southern sea borders, 2013, at < http://fra.europa.eu/en/publication/2013/
} 
Specific issues arise when irregular migration by sea is at stake. Recent experience shows a significant variety of techniques, constantly adapted by smugglers in order to circumvent contrast strategies by coastal States: hiding of stowaways in ferries or cargoes in regular service ${ }^{7}$; arrivals on board old ships in bad conditions and overloaded; use of small boats driven by the migrants themselves and completely unsuited for long journeys (being usually devoted to short-term fishing); employment of speed rubber dinghies and quick unloading of migrants, often before reaching dry land and with brutal modalities, if necessary, in order to avoid interception by the coast guard ${ }^{8}$ and, lastly, carrying out the major part of the journey by means of a medium- or large-sized boat that stops at the limit of territorial waters, disembarking migrants with light launches that go back and forth between the coast and the 'mother' boat.'

Practice highlights the growingly dangerous nature of such movements and the occurrence of tragic outcomes, about which precise statistics are inherently unavailable. ${ }^{10}$ In addition, such flows are very often mixed, in the sense that persons attempting irregular entry may be, at the same time, ordinary migrants, individuals in need of international protection (either from the departure state or their own state, when different ${ }^{11}$ ) or other vulnerable persons (unaccompanied minors, sick persons, victims of trafficking, pregnant women).

The issue at stake proves difficult because an ad hoc international regulation does not exist and destination countries may find themselves in the uncomfortable position of tolerating arrivals without being able to effectively contrast them, if genuine adherence to human rights standards is to be ensured (and smugglers know it perfectly). An overview of applicable international rules, of different origin, confirms such an impression: provisions on jurisdiction over maritime zones and on related coercive powers; obligations on safeguard of life at sea and on search and rescue of persons in distress; rules on human rights, especially the ones

fundamental-rights-europes-southern-sea-borders> (hereinafter, the FRA study).

${ }^{7}$ This issue will not be treated here, the attention being focused on journeys and boats entirely devoted to irregular migration: for a discussion of problems raised by stowaways, see among others BASTID-BURDEAU, G., 'Migrations clandestines et droit de la mer', in La mer et son droit. Melanges offerts a Laurent Lucchini et Jean-Pierre Quénedec, A. Pedone, Paris, 2003, p. 5, at pp. 60-64.

${ }^{8}$ From Albania and Montenegro to Italy in the $1990 \mathrm{~s}$, from Somalia and other countries to Yemen in the Aden Gulf nowadays.

${ }^{9}$ See the cases described in IMO Circular MSC/Circ. 896, Rev. 1.

${ }^{10}$ See, for instance, the data reported in SPIJKERBOER, T., loc. cit., pp. 6-7; WEINZIERL, R., LISSON, U., loc. cit., p. 18; Parliamentary Assembly of the Council of Europe, Lives Lost in the Mediterranean Sea: Who Is Responsible?, report presented by T. Strik to the Committee on Migration, Refugees and Displaced Persons, Doc. 12895, 5 April 2012; the FRA study, pp. 19-28. Additionally, see three sources, very different in nature but converging in drawing attention to the same problem: the UNHCR website section on mixed migration flows $<$ www.unhcr.org/cgi-bin/texis/vtx/asylum>; the biannual circulars issued by the IMO Maritime Safety Committee on 'Unsafe practices associated with the trafficking or transport of illegal migrants by sea' $<$ www.imo.org $>$; the data reported on the website Fortress Europe $<\mathrm{http}$ ://fortresseurope.blogspot.com>.

${ }^{11}$ Among the various sources on this subject, reference can be made to the web page $<$ www.unhcr.org/cgi-bin/ texis/vtx/asylum $>$ and to the special issue of the UNHCR review Refugee, entitled 'Refugee or Migrant. Why It Matters', Vol. 148, 2007, No. 4. 
concerning the right to leave a country and the protection of persons in need of international protection, including refugees. ${ }^{12}$

The purpose of this article is to scrutinize only a part of the relevant rules, namely the international provisions concerning safeguard of life at sea in order to check whether the resulting framework is coherent or whether there is a contradiction or a tension between their abstract content and their practical enforcement. Particular emphasis will be placed on the Mediterranean Basin, on the solutions envisaged (or proposed) in International Maritime Organization (IMO) circles and on the role of the EU and the ultimate effect of its rules and policy choices. It will be demonstrated that some shortcomings and defects of maritime law currently in force are owed to underlying policy choices (mainly of European states and of the European Union) which should be seriously addressed in order to comprehensively tackle the challenges posed by irregular migration by sea and by the tragic outcome of many voyages.

\section{OBLIGATIONS AIMED AT SAFEGUARDING LIFE AT SEA: THE RELEVANT TREATY RULES}

In the last few decades, the long-established maritime custom to provide comfort and take on board shipwrecked persons and those whose life is at risk has found wide recognition in positive international law. The United Nations (UN) and, especially, IMO devoted much attention to this issue, as witnessed by several treaties and related instruments.

The United Nations Convention on the Law of Sea (UNCLOS) treats this topic in a general character provision, stating that every state shall require the master of a ship flying its flag - in so far as he can do so without serious danger to the ship, the crew or the passengers - to render assistance to any person found at sea in danger of being lost; to proceed with all possible speed to the rescue of persons in distress, if informed of their need for assistance, in so far as such action may reasonably be expected of him. In addition, every coastal state shall promote the establishment, operation and maintenance of an adequate and effective search

\footnotetext{
${ }^{12}$ For a comprehensive overview of the various issues at stake, see (also for additional references) FISCHERLESCANO, A., LÖHR, T., TOHIDIPUR, T., 'Border Controls at Sea: Requirements Under International Human Rights and Refugee Law', International Journal of Refugee Law, Vol. 21, 2009, p. 265; BARNES, R., 'The International Law of the Sea and Migration Control', in RYAN, B., MITSILEGAS, V. (Eds.), Extraterritorial Migration Control: Legal Challenges, Martinus Nijhoff, Leiden, 2010, p. 103; MORENO-LAX, V., 'Seeking Asylum in the Mediterranean: Against a Fragmentary Reading of EU Member States' Obligations Accruing at Sea', International Journal of Refugee Law, Vol. 23, 2011, p. 174; TREVISANUT, S., Immigrazione irregolare via mare. Diritto internazionale e diritto dell'Unione europea, Jovene, Napoli, 2012; RIJPMA, J.J., 'The Patrolling of the European Union's External Maritime Border: Preventing the Rule of Law From Getting Lost at Sea', in DEL VECCHIO, A. (ed.), International Law of the Sea: Current Trends and Controversial Issues, Eleven International Publishing, The Hague, forthcoming 2013, § 4.2. On the non refoulement principle and its scope of application, see (also for additional references) DI FILIPPO, M., 'L'ammissione di cittadini stranieri', in CALAMIA, A.,M, DI FILIPPO, M., GESTRI, M. (eds.), Immigrazione, Diritto e Diritti: profili internazionalistici ed europei, Cedam, Padova, 2012, p. 81, at 92-113.
} 
and rescue service regarding safety on and over the sea and, where circumstances so require, by way of mutual regional arrangements, cooperate with neighbouring states for this purpose (see Article 98, paragraph 2).

A more detailed regulation of those issues can be found, however, in two older IMO Conventions, adopted in the seventies and amended on various occasions thanks to a simplified revision mechanism. According to the regulation in force before some recent amendments took effect (see below, \4), the International Convention for the Safeguard of Life at Sea, adopted in London on 1 November 1974 (hereinafter, SOLAS Convention), ${ }^{13}$ provided that the master of a ship at sea that is in a position to be able to provide assistance, on receiving a signal from any source that persons are in distress at sea, is bound to proceed with all speed to their assistance, if possible informing them or the search and rescue service that the ship is doing $\mathrm{sO}^{14}$; moreover, the Convention required each contracting government to ensure that necessary arrangements are made for distress communication and coordination in its area of responsibility and for rescue of persons in distress at sea around its coast. These arrangements shall include the establishment, operation and maintenance of such search and rescue facilities as are deemed practicable and necessary, having regard to the density of the seagoing traffic and the navigational dangers, and shall, so far as possible, provide adequate means of locating and rescuing such persons. ${ }^{15}$

The International Convention on Search and Rescue at Sea, adopted in Hamburg on 27 April 1979 (hereinafter, SAR Convention), ${ }^{16}$ reiterated the duty to set up SAR areas and the related rapid intervention services and added that parties shall ensure that assistance is provided to any person in distress at sea, doing it regardless of the nationality or status of such a person or the circumstances in which the person is found, ${ }^{17}$ and that an operation to retrieve persons in distress provides for their initial medical treatment or other needs and delivers them to a place of safety. ${ }^{18}$

Against this background, it arises that both the master of a vessel (no matter whether official or private) and the states (especially the one territorially competent for the relevant SAR region) must comply with several obligations, occasionally of a certain degree of intensity. Hence, it comes out that a state acting on the high seas with a view to protecting its maritime borders from unauthorized entries may be compelled to carry out an activity of first assistance and taking on board of irregular migrants, not being allowed to ignore their actual conditions

\footnotetext{
${ }^{13}$ Entered into force on 25 May 1980; 162 Contracting States as of 31 January 2013.

${ }^{14}$ See Chapter V, Reg. 33, para. 1.

${ }^{15}$ See Chapter V, Reg. 7.

${ }^{16}$ Entered into force on 22 June 1985; 104 Contracting States as of 31 January 2013.

${ }^{17}$ Chapter 2.1.10.

${ }^{18}$ Chapter 1.3.2.
} 
and need for rescue. ${ }^{19}$ It is worth noting that intervention in favour of a vessel in need of rescue is a duty and is not made conditional on its nationality.

Additionally, the above-mentioned treaty-based regimes did not solve every practical question: they present some interpretative doubts, require a proper implementation by states parties, and need the conclusion of regional or bilateral agreements concerning the delimitation of SAR zones and the coordination of their activities. When coming to the law in action (especially in the Mediterranean Sea), we must face several problems that are able to produce a crises of the rescue regime drafted by the relevant conventions. As aptly observed, "current concerns relating to rescue at sea are largely associated with irregular migration rather than with accidents or the malfunction of vessels at sea," ${ }^{20}$ and "international legal norms are faced with developments unforeseen at the time of their drafting," while "these same international norms are the only ones which apply in these new scenarios." 21

\section{EU LAW AND SAR MATTERS}

Before examining the main controversial issues, it must be added that the presence of the EU increases complexity in the subject matter. The EU is not party to the SOLAS and SAR Conventions, but is party to the UNCLOS, although its declaration of competence does not include SAR matters ${ }^{22}$. However, some aspects of EU law may exacerbate current controversies concerning search and rescue activities. For instance, under the legislation currently in force (Dublin Regulation, Schengen Borders Code, Return Directive ${ }^{23}$ ), a principle may be derived according to which asylum seekers, refugees and irregular migrants must be taken in charge by the state whose borders have been first crossed. Notwithstanding the enunciation of a general principle of intra-EU solidarity in Article 80 TFEU, ${ }^{24}$ there is no permanent and automatic mechanism of burden sharing among EU Member States with regard to irregular migratory

\footnotetext{
${ }^{19}$ Additionally, see the cases described by HINRICHS, X., loc. cit., pp. 445-447.

${ }^{20}$ KLEIN, N., 'International Migration by Sea and Air', in OPESKIN, B., PERRUCHOUD, R., REDPATHCROSS, J. (Eds.), Foundations of International Migration Law, Cambridge University Press, Cambridge, 2012, p. 260 , at p. 275 .

${ }^{21}$ MALLIA, P., Migrant Smuggling by Sea. Combating a Current Threat to Maritime Security Through the Creation of a Cooperative Framework, Martinus Nijhoff, Leiden, 2010, p. 97.

${ }^{22}$ Since the entry into force of the Lisbon Treaty, the European Union succeeded to the legal obligations attributable to the European Community, which originally accessed the UNCLOS.

${ }^{23}$ For a description of such normative framework, see Rijpma 2013, § 4.3.

${ }^{24}$ Art. 80 reads as follows: "The policies of the Union set out in this Chapter and their implementation shall be governed by the principle of solidarity and fair sharing of responsibility, including its financial implications, between the Member States. Whenever necessary, the Union acts adopted pursuant to this Chapter shall contain appropriate measures to give effect to this principle." On the issue of intra-EU solidarity, see GESTRI, M., 'La politica europea dell'immigrazione: solidarietà tra Stati membri e misure nazionali di regolarizzazione', in LIGUSTRO, A., SACERDOTI, G. (eds.), Problemi e tendenze del diritto internazionale dell'economia. Liber amicorum in onore di Paolo Picone, Editoriale Scientifica, Napoli, 2011, p. 895; DI FILIPPO, M., 'La circolazione dello straniero nel diritto dell'Unione europea : una geometria variabile dei diritti e delle garanzie', in CALAMIA, A.M., DI FILIPPO, M., GESTRI, M. loc. cit., p. 159, at 264-268.
} 
flows, by both land and sea.

In favour of a particularly affected Member State, four main tools may be activated under procedures that are not excessively based upon political circumstances:

- Joint Frontex operations coordinated by Frontex, such as HERMES 2011, which was launched on 20 February 2011 to help Italy with maritime border surveillance, identification of migrants and refugees as well as search and rescue operations at sea;

- Rapid Border Intervention Teams (RABITs) deployed by Frontex after a request from a Member State in need of help for managing border controls. This tool, was first employed in 2010, in favour of Greece, faced with an extraordinary incoming flow at the land border with Turkey;

- Financial assistance to be mobilised, especially under the External Borders Fund and European Refugee Fund, or even under the European Return Fund;

- Asylum Support Teams (AST), multidisciplinary teams of EU experts deployed by the European Asylum Support Office (EASO) in a Member State for a limited time in order to back the asylum system of that Member State. Even in this case, Greece was the first country to ask for this emergency support in 2011.

Additionally, two other tools may be activated, more strictly dependent on the political will of other Member States: voluntary relocation schemes, such as the one called Eurema, launched in 2009-2012 in favour of Malta, concerning around 600 refugees (twelve Member States and three third states agreed to relocate refugees disembarked at Malta ${ }^{25}$; temporary protection under Directive 2001/55, never enforced.

In practice, the state whose ship is conducting a SAR operation or the state responsible for the relevant SAR region, on accepting disembarkation, may be compelled by EU law to face the consequent burden (asylum seekers and refugees to accommodate; processing of asylum claims; irregular migrants to manage and eventually return to origin or transit countries). While some help in managing the situation on the ground may be obtained through the four tools listed above, the perspective of obtaining more robust solidarity (a relocation voluntary scheme, or the activation of the mechanisms regulated in Directive 2001/55) is conditioned by contingent and political aspects. Such a situation created some reluctance in Member States with regard to participation in Frontex operations with their official ships (preferring, in the case of participation, to deploy helicopters, airplanes or other facilities) or to the hosting of the operation itself.

\footnotetext{
${ }^{25}$ See the press release of 12 May 2011, at <http://ec.europa.eu/malta/news/over_300_refugees_resettled en.htm>; the Statement by Cecilia Malmström, EU Commissioner in charge of Home Affairs, on the results of the Ministerial Pledging Conference (12 May 2011), Doc. MEMO/11/295 of 13 May 2011; European Asylum Support Office, EUREMA Fact Finding Report on Intra-EU Relocation Activities From Malta, July 2012, at $<$ http://easo.europa.eu/wp-content/uploads/EUREMA-fact-finding-report-EASO1.pdf $>$; the FRA study, pp. 112113.
} 
In 2010, the EU Council approved the Decision No. 2010/252 of 26 April 2010, supplementing the Schengen Borders Code as regards the surveillance of the sea external borders in the context of operational cooperation coordinated by Frontex. ${ }^{26}$ This Decision contains guidelines only for the Frontex-led operations and not for activities carried out by Member States in their autonomy. Moreover, it is divided into two parts, one binding and one merely recommendatory. This being said, the Decision is an important tool of reference for international practice. In the binding part, interesting clarifications are made on the extension of coercive powers on ships without nationality and, especially, on the prohibition to disembark persons in places that may be unsafe from a non-refoulement perspective. In the recommendatory part, SAR matters are directly treated. In the following analysis the relevant part of the Decision will be recalled. ${ }^{27}$

\section{CONTROVERSIAL ISSUES, WITH SPECIAL REGARD TO THE MEDITERRANEAN SEA}

When examining the actual degree of implementation of the international rules on the safety of life at sea, a first problematic issue that we see is the fragmentary state of affairs as far as the drafting of regional or bilateral treaties on the delimitation of SAR areas is concerned. Focusing on the Mediterranean Basin, a provisional plan was adopted by IMO in the 1997 Conference of Valencia, as a framework of reference for the Mediterranean Sea and the Black Sea, open to additional specification at state's level and to integration by means of more detailed bilateral and regional agreements. ${ }^{28}$ Unfortunately, the discussions carried out in Valencia among the states of Central Mediterranean (absent Algeria and Libya) were unfruitful, and did not allow to reach a consensus. In particular, the area delimited by the coasts of Italy, Malta and Libya raises various problems. Both Malta ${ }^{29}$ and Italy ${ }^{30}$ unilaterally

\footnotetext{
${ }^{26}$ OJ 2010 L 111/20.

${ }^{27}$ It must be added that the EU Court of Justice declared the invalidity of this decision, owing to procedural faults: Court of Justice (Grand Chamber), Judgment of 5 September 2012 case C-355/10, European Parliament $v$. Council of the European Union, not yet published. The judgment of the Court does not contest the substance per se of the Decision, but only the procedure followed to enact rules, which require political choices falling within the responsibilities of the EU legislature. Additionally, the effects of the contested decision are maintained until the entry into force, within a reasonable time, of new rules intended to replace the annulled decision. In Spring 2013, the European Commission presented a proposal for a new regulation, to be adopted with the legislative procedure: see Doc. COM (2013) 197 final, 12 April 2013, § 3.4. Where containing elements of interest, also the proposal will be quoted.

${ }_{28}$ See the 'General Agreement on a Provisional SAR Plan', adopted during the IMO Conference held in Valencia (8-12 September 1997), as Ann. 1 to the Res. 1.

${ }^{29}$ See the map and the information reported at <www.sarmalta.gov.mt/sar_in_Malta.htm $>$ and in IMO Circular SAR.8/Circ.1/Corr.3, 20 October 2005, Global Sar Plan Containing Information on the Current Availability of Sar Services, Ann. $2<$ www.imo.org/includes/blastDataOnly.asp/data_id\%3D16608/1-Corr-3.pdf>, p. 25.

${ }^{30}$ See the map annexed to Presidential Decree (D.P.R.) No. 660/1994 and in IMO Circular SAR.8/Circ.1/ Corr.5, 23 April 2007, Global Sar Plan Containing Information on the Current Availability of Sar Services $<\mathrm{www}$. imo.org/includes/blastDataOnly.asp/data_id\%3D18744/1-Corr-5.pdf>, p. 26.
} 
established SAR zones, partially overlapping. The extension of the Maltese SAR area appears to be excessive, paying due regard to the country's capacity to warrant adequate coverage and to the circumstance that it includes the Italian islands of Lampedusa and Lampione and the surrounding territorial waters. ${ }^{31}$ As far as Libya is concerned, it is not sure that a formal establishment of the SAR followed the adhesion to the SAR Convention. ${ }^{32}$ It should be noted, however, that in the past the Maltese government often referred to the Libyan SAR area when dealing with distress situations involving disembarkation issues of migrants rescued there; moreover, on 18 March 2009, Libya and Malta signed a "Memorandum of Understanding $(\mathrm{MoU})$ in the field of search and rescue," aimed at coordinating the search and rescue operations within their respective SAR regions. ${ }^{33}$ In any case, it is certain that during the last few years, the issues of the unsatisfactory fulfilment of search and rescue and of the insufficient cooperation with other states involved in SAR operations in the waters included in the Libyan SAR region or otherwise proximate have often been raised. ${ }^{34}$

The above-mentioned difficulties are not shared by any part of the Mediterranean Basin.

${ }^{31}$ It has been reported that "The reasons for this enormous SAR area are historical and are also connected to
the lucrative income Malta derives from its Flight Information Region (FIR). The size of the SAR region is bound
to the Maltese FIR. Malta is earning around $€ 8.23$ million yearly for air traffic passing over its SAR/FIR region":
see KLEPP, S., 'A Double Bind: Malta and the Rescue of Unwanted Migrants at Sea, a Legal Anthropological
Perspective on the Humanitarian Law of the Sea', International Journal of Refugee Law, Vol. 23, 2011, p. 538, at p. 545 .

The anomalies of the Malta SAR zone may be addressed only following the conclusion of dedicated delimitation and cooperation agreements with neighbouring countries. With Greece, an Agreement on Cooperation in the Field of Search and Rescue was signed on 12 January 2008 (and ratified by Malta on 3 April 2008) but has not yet entered into force; see <www.foreign.gov.mt/TreatyDetails.aspx?id=583>: it delegates to Greek authorities the coordination of SAR activities over a broad portion of the eastern Maltese SAR region.

As far Italy is concerned, some rounds of negotiation in recent years did not produce a decisive outcome. As reported by the then legal advisor of Italy (Professor Umberto Leanza), in September 1999 a substantive understanding had been reached on a draft framework agreement, under whose terms subsequent technical arrangements on specific items (SAR matters among others) would have been concluded between the parties. In 2002 the framework agreement reached the stage of signature, but contrasts arose as to the possible content of related technical arrangements: see 'Framework Agreement for Aero-maritime Surveillance in the Mediterranean for the Fight Against Illegal Trafficking at Sea, With Particular Reference to Those Activities Which Directly Cause Harm to Customs and Revenue', signed on 20 December 2002, entered into force on 31 July 2003; for the text, see $<$ www.foreign.gov.mt/TreatyDownloader.aspx?id=255>. A new round of negotiations took place between 2002 and 2005, but apparently no technical arrangements were finalized. For additional details, see LEANZA, U., 'Maritime Safety and Security Within Mediterranean Context: Strategic Outlines', reprinted in the proceedings of the 1st Mediterranean Coast Guard Services Forum, held in Genoa on 6-7 May 2009, at <www. guardiacostiera.it/medforum/agenda.cfm>, p. 12.

${ }^{32}$ See the Commission Working Document, qtd. at p. 5, note 4; Leanza 2009, p. 11. Besides, the relevant IMO Circulars on Global Sar Plan Containing Information on the Current Availability of Sar Services do not report any information regarding Libya SAR zone and services, notwithstanding Libya's quality of contracting States of the SAR Convention: lastly, see Doc. SAR.8/Circ.4, 1 December 2012. Libya formally accessed the SAR Convention in 2005, and the SOLAS Convention in 1981.

33 See <www.mfa.gov.mt/default.aspx?MDIS=21\&NWID=322>. The text is not made public and no information on its status is available on the Maltese MFA website.

${ }^{34}$ See the Commission Working Document, qtd. at p. 5 and p. 33, where it is stated that "the waters neighbouring Libya are not subject to SAR patrols" and that there are still some areas where SAR services are not provided at the moment by the State mainly responsible (for instance in the waters around Libya). See also the FRA study, pp. 32-33. 
In fact, it may be recalled that in the Ionic and Adriatic seas a consensus was found during the talks in Valencia and that some years later (2000) a treaty-based regime, rather satisfactory, was defined by the interested states. ${ }^{35}$

A second problematic issue is represented by the notion of distress. It may be wondered whether it embraces a self-induced situation of danger (in order to claim rescue by the authorities of a prospective destination country) or the commencement of a risky voyage on an unseaworthy vessel. Contrary to what has been suggested by a commentator, ${ }^{36}$ I share the view that distress is an objective situation, which calls for rescue by ships that are able to intervene, irrespective of the genesis of it. ${ }^{37}$ Rather than exempting from rescue duties, such a scenario might lead to consequences of another kind : interested states could impose sanctions on smugglers (when identifiable) and prevent or interrupt risky voyages even just outside the harbours of the departure country and in the adjacent waters: in such cases, these reactions might well be deemed legitimate restrictions on the right to leave a country, under Article 12, paragraph 3 of the 1966 UN International Covenant on Civil and Political Rights and under Article 2, paragraph 3 of the 4th Additional Protocol to the ECHR. ${ }^{38}$

A third question arises with the same concept of rescue. Does it imply taking on board the persons in danger, or escorting their vessel to a safe harbour? Or would it be sufficient to merely provide water, food, basic sanitary assistance and fuel and allow the vessel to continue its journey when it is self-evident that an attempt of irregular entry into another state's territory will be realized? Sometimes, the latter interpretation has been advanced as a justification for not interfering with the 'sacred' freedom of navigation, especially when the migrants reportedly expressed the will to continue the journey. ${ }^{39}$ If it is clear beyond all doubt that any situation requires an ad hoc evaluation, in general terms, however, it must be stressed that freedom of navigation is accorded only to vessels that fulfil a set of requisites, including

${ }^{35}$ During the Ancona Conference of 19 May 2000, Italy concluded several Memoranda of Understanding with Albania, Croatia, Greece, and Slovenia: see GESTRI, M., 'I rapporti di vicinato marittimo tra 1'Italia e gli Stati nati dalla dissoluzione della Iugoslavia', in RONZITTI, N. (Ed.), I rapporti di vicinato dell'Italia con Croazia, Serbia-Montenegro e Slovenia, Luiss University Press-Giuffré, Rome-Milan, 2005, p. 177, at pp. $207-$ 211; TASSI, A., 'Le zone di ricerca e soccorso in Mediterraneo', Rivista Marittima, Vol. 146, No. 4, 2007, p. 31, at p. 33 .

As for other parts of the Mediterranean Sea, a critical issue is represented by the delimitation of SAR zones between Greece and Turkey: on this subject, see TREVISANUT, S., 'Search and Rescue Operations in the Mediterranean: Factor of Cooperation or Conflict?', The International Journal of Marine and Coastal Law, Vol. 25, 2010, p. 523, at pp. 532-534; MARINAI, S., 'The Action of Greece and Spain Against Irregular Migration by Sea', in DEL VECCHIO, A. (ed.), loc. cit., \$2.10 (therein additional references).

${ }^{36}$ See PUGH, M., 'Europe's Boat People: Maritime Cooperation in the Mediterranean', Chaillot Paper No. 41, July 2000, p. 57.

${ }^{37}$ See MALLIA, P., loc. cit., p. 98.

${ }^{38}$ This being said, it must be underlined that other aspects might arise, under a human rights' perspective: see below, in the text.

${ }^{39}$ See the references to Maltese practice made by CAFFIO, F., 'Un accordo euromediterraneo per il salvataggio dei migranti', Affari internazionali, 6 June 2011 <www.affarinternazionali.it/articolo.asp?ID=1776>; KLEPP, S., loc. cit., pp. 552-554 and p. 557; FRA study, p. 34. 
that of being registered under a state's flag, showing its flag, satisfying minimum requisites of safety and seaworthiness and being manned by a duly trained commander and crew. Thus, absent such requirements, the rescuing unit should prefer an interpretation of its duties based upon good faith and the assumption of responsibility rather than on the hope that migrants will sail towards another state's shores. Moreover, when two EU Member States are involved, the duty of solidarity (spelled in Article 4, paragraph 3 TEU and Article 80 TFEU) is hardly compatible with a 'turn away the eyes' policy by the intervening unit.

Fourthly, maritime law requires delivery of rescued persons as soon as possible to a place of safety, which is defined as a location where rescue operations are considered to terminate, and where the survivors' safety or life is no longer threatened, basic human needs (such as food, shelter and medical needs) can be met and transportation arrangements can be made for the survivors' next or final destination. ${ }^{40}$ A restrictive interpretation of the notion might lead to the consideration that a port of any country where such basic needs are satisfied would match the requirements of a place of safety, irrespective of the quality of the rescued persons and of the possible need for international protection. ${ }^{41}$ However, a wider construction of the concept of place of safety is advanced by many commentators, ${ }^{42}$ having due regard to converging data of international practice (IMO Guidelines, ${ }^{43}$ United Nations High Commissioner for Refugees-UNHCR positions, ${ }^{44} \mathrm{EU}$ orientations $\left.{ }^{45}\right)$ : a location is safe when no risk of refoulement

${ }^{40}$ See IMO Guidelines on the Treatment of Persons Rescued at Sea, Doc. MSC.167(78), 20 May 2005, Principle 6.12.

${ }^{41}$ This seems to be the position of Maltese authorities, according to KLEPP, S., loc. cit., pp. 549-550.

${ }^{42}$ See WEINZIERL, R., LISSON, U., loc. cit.; TREVISANUT, S., 'The Principle of Non-Refoulement at Sea and the Effectiveness of Asylum Protection', Max Planck Yearbook of United Nations Law, Vol. 12, 2008, p. 205; FISCHER-LESCANO, A., LÖHR, T., TOHIDIPUR, T., loc. cit., p. 291; WOUTERS, K., DEN HEIJER, M., 'The Marine I Case: A Comment', International Journal of Refugee Law, Vol. 22, 2010, p. 1; MORENO-LAX, V., loc. cit., pp. 199-200; TONDINI, M., 'The Legality of the Interception of Boat People Under Search and Rescue and Border Control Operations', Journal of International Maritime Law, Vol. 18, 2012, p. 59, at pp. 63-65.

${ }^{43}$ For this view, see the Principle 6.17 contained in the IMO Guidelines on the Treatment of Persons Rescued at Sea: "The need to avoid disembarkation in territories where the lives and freedoms of those alleging a wellfounded fear of persecution would be threatened is a consideration in the case of asylum-seekers and refugees recovered at sea. / La nécessité d'éviter le débarquement dans des territoires où la vie et la liberté des personnes qui affirment avoir des craintes bien fondées de persécution seraient menacées est à prendre en compte dans le cas de demandeurs d'asile et de réfugiés récupérés en mer" (emphasis added).

${ }^{44}$ See IMO \& UNHCR, Rescue at Sea. A Guide to Principles and Practice as Applied to Migrants and Refugees, qtd. at pp. 7-10; UNHCR, Background Paper for the Expert Meeting in Djibouti (8-10 November 2011). Refugees and Asylum-Seekers in Distress at Sea - How Best to Respond?, October 2011, qtd. at Ann. A, $\S$ III.2, p. 7.

${ }^{45}$ Council Decision 2010/252 of 26 April 2010. In Part I of the Decision (of a binding nature), $\S 1.2$ reads as follows: "No person shall be disembarked in, or otherwise handed over to the authorities of, a country in contravention of the principle of non-refoulement, or from which there is a risk of expulsion or return to another country in contravention of that principle. Without prejudice to paragraph 1.1, the persons intercepted or rescued shall be informed in an appropriate way so that they can express any reasons for believing that disembarkation in the proposed place would be in breach of the principle of non-refoulement". In even stricter terms, see the proposal for a new regulation, replacing such decision and contained in Doc. COM (2013) 197, qtd., under Article 4. 
arises and where basic human rights of migrants and asylum seekers are respected. ${ }^{46}$ As a consequence, depending on the presence of asylum seekers or other vulnerable persons on the vessel in distress, "the arrangements made in regard to some of those rescued may not be valid for others." 47

This clarification is even more important as far as flagless vessels are concerned. For a public ship engaged in controls over irregular migration, a SAR intervention and the subsequent transportation of migrants to a port may appear as an easy way to assert jurisdiction on persons and boats, even where doubt might be raised about their exact journey, their behaviour and the prospective final destination. Asserting a situation of distress allows one to immediately intervene and then to disembark persons, in a national port ${ }^{48}$ or in the port of a third country (for instance, the departure one, or a transit one) that has expressed its consent, mainly in the context of a bilateral cooperation agreement on combating irregular migration by sea. Should the place of safety be meant to be just a shelter from sinking and starving, serious deficits as to the protection of human rights and respect of the non-refoulement principle might arise.

Last, but not least, the actual identification of the place of disembarkation put the SAR system under high pressure. Which state must allow disembarkation of the rescued persons

\footnotetext{
${ }^{46}$ On the strictly related issue of the extraterritorial application of human rights law and of the principle of non refoulement, see the authors cited in note 12. For its relevance, here a reference must be made to ECtHR (Grand Chamber), Judgment of 23 February 2012, Application No. 27765/09, Hirsi Jamaa and others v. Italy. This landmark judgment has been object of several comments, given that it asserted the contrariness to Article 3 of the ECHR (prohibiting torture and inhuman and degrading treatments) and to Article 4 of the Fourth Protocol to the ECHR (prohibiting collective expulsions) of the Italian practice of push-back to Libya of ships intercepted mainly in the high seas on their prospective route to Italy or to other European shores: see, among others, CARELLA, G., 'Il divieto di respingimenti in mare, il caso Hirsi Jamaa e l'isola che non c'è', Sud in Europa, 2012, No. 1, p. 5; CALLAMARE, G., 'La sentenza Hirsi Jamaa e la "nuova fase di cooperazione" tra Italia e Libia nel settore migratorio', Sud in Europa, No. 2, 2012, p. 3; GIUFFRÉ, M., 'State Responsibility Beyond Borders: What Legal Basis for Italy's Push-backs to Libya?', International Journal of Refugee Law, Vol. 24, 2012, p. 692; LIGUORI, A., 'La Corte europea dei diritti dell'uomo condanna l'Italia per i respingimenti verso la Libia del 2009: il caso Hirsi', Rivista di Diritto Internazionale, Vol. 95, 2012, p. 415; NAPOLETANO, N., 'La condanna dei "respingimenti" operati dall'Italia verso la Libia da parte della Corte europea dei diritti umani: molte luci e qualche ombra', Diritti umani e diritto internazionale, Vol. 6, 2012, p. 436; NASCIMBENE, B., 'Condanna senza appello per i «respingimenti»’, Affari internazionali, 10 March 2012 (at $<\mathrm{http}$ ://www.affarinternazionali. it/articolo.asp?ID=1988>); TONDINI, M., 'The legality of intercepting boat people under search and rescue and border control operations with reference to recent Italian interventions in the Mediterranean Sea and the ECtHR decision in the Hirsi case', Journal of International Maritime Law, Vol. 18, 2012, p. 59.

More recently, some debate was provoked by the decision taken in early August 2013 by Italian and Maltese authorities to order two private rescuing units to take the migrants to Libyan port of Tripoli: see FRENZEN, N., Italy Conducted De Facto Push-Back of Migrants By Ordering Cargo Ship to Rescue and Transport Migrants to Libya, 13 August 2013, at <http://migrantsatsea.wordpress.com/2013/08/13/italy-conducted-de-facto-push-backof-migrants-by-ordering-cargo-ship-to-rescue-and-transport-migrants-to-libya $>$. See also M. Dalli, 'Government warns Salamis's local agent to take migrants back to Tripoli', Malta Today, 5 August 2013 (at <http://www. maltatoday.com.mt/en/newsdetails/news/national/Government-warns-Salamis-local-agent-migrants-must-betaken-back-to-Tripoli-20130805>, reproducing the text of the letter sent by Maltese authorities to the local agent for the rescuing unit Salamis); F. Caffio, 'Nodi irrisolti nel Mediterraneo dei migranti', Affari internazionali, 12 August 2013, at <http://www.affarinternazionali.it/articolo.asp?ID=2388>.

${ }^{47}$ See MORENO-LAX, V., loc. cit., p. 198.

${ }^{48}$ Thus avoiding lengthy and costly activities of surveillance over the vessel concerned: once disembarked, rescued persons might be, depending on the circumstances, removed to origin or transit countries.
} 
after the first emergency intervention? The generic reference often made to the 'next port of call' in some writings or in UNHCR statements is devoid of a precise legal meaning and is absent from international maritime law treaties. ${ }^{49}$ At the same time, such treaties do not identify a precise responsibility to accept rescued persons for any state. Generally speaking, several states, having links with the situation, may be deemed potentially interested for disembarkation: the flag state of the rescuing unit or of the vessel in distress; the next port of call on the rescuing ship's planned route; the closest port to the place where the rescue occurred; the state from which the vessel took the sea; the state competent for the relevant SAR zone; the countries of nationality of those rescued.

The problems are particularly serious for rescuing private ships, which may be subjected to economic losses and complications, given that it is not always easy to prosecute the original route. Practice shows that a rescue at sea by private vessels may be followed by a refusal of the nearest state or the state territorially competent for the relevant SAR zone to accept the disembarkation of the migrants, ${ }^{50}$ or by the master having difficulty in convincing such authorities of not being involved in smuggling of migrants. ${ }^{51}$ Sometimes, the mess is total, as the case concerning the Maltese fishing boat Budafel shows. ${ }^{52}$ For public ships, inconveniences are not any lesser, leading to situations where the only accessible solution may be represented

\footnotetext{
${ }^{49}$ As to possible meanings, depending on the actual situation, see UNHCR, Background Note on the Protection of Asylum-Seekers and Refugees Rescued at Sea, 18 March 2002, § 30.1: the Note was discussed at the expert round table 'Rescue-at-Sea: Specific Aspects Relating to the Protection of Asylum-Seekers and Refugees', held in Lisbon, Portugal on 25-26 March 2002.

${ }^{50}$ See the famous case of the Norwegian boat 'Tampa', occurred in 2001, on which see FORNANI, M.N., 'Soccorso in mare di profughi e diritto di asilo: questioni di diritto internazionale sollevate dalle vicende della nave Tampa', La Comunità Internazionale, Vol. 57, 2002, p. 61; MATHEW, P., 'Australian Refugee Protection in the Wake of the Tampa', American Journal of International Law, Vol. 96, 2002, p. 661; WHITE, M., 'M/V Tampa Incident and Shipping Obligations of a Coastal State', Indian Journal of International Law, Vol. 44, 2003 , p. 314. More recently, similar cases took place in the waters between Malta and Libya, involving Spanish fishing boats ('Francisco Catilina' in July 2006; 'Monfalcó' in May 2007) not allowed to disembark either in Malta or in Libya, migrants rescued in a situation of clear distress: some days later, migrants were accepted by Spain and other European countries (see UNHCR, Press Briefing, 1 June 2007; El Pais, 4 June 2007). For further details on other cases, see MILTNER, B., 'Irregular Maritime Migration: Refugee Protection Issues in Rescue and Interception', Fordham International Law Journal, Vol. 30, 2006, p. 75, at pp. 87-89; COPPENS, J., SOMERS, E., 'Towards New Rules on Disembarkation of Persons Rescued at Sea?', The International Journal of Marine and Coastal Law, Vol. 25, 2010, p. 377, at pp. 379-381; MARINAI, S., loc. cit., 2013, § 2.10.

${ }^{51}$ See the Cap Anamur case (2004) and the indictment of some Tunisian fishermen (2007), both concerning Italy. For some interesting comments, TREVISANUT, S. 'Le Cap Anamur: profils de droit international et de droit de la mer', Annuaire du Droit de la Mer, 2004, Vol. 9, p. 49; DI PASCALE, A., 'Migration Control at Sea: The Italian Case', in RYAN, B., MITSILEGAS, V. (Eds.), Extraterritorial Migration Control: Legal Challenges, Martinus Nijhoff, Leiden, 2010, p. 281, at pp. 302-304. On 7 October 2009 the Tribunal of Agrigento acquitted the convicted persons of their charges in the Cap Anamur trial. Similarly, on 21 September 2011 the Court of Appeal of Palermo acquitted the Tunisian fishermen of the charge of smuggling of migrants and of disobedience towards public authorities.

52 See the account given by various sources: UNHCR, Press Briefing, 1 June 2007; La Repubblica, 27 May 2007 and 29 May 2007; the report from the Italian NGO Consiglio italiano rifugiati, presented during an EP public hearing <www.europarl.europa.eu/hearings/20070703/libe/cir_report_en.pdf>; the version from the Maltese government, included in a document presented in the same hearing <www.europarl.europa.eu/ hearings/20070703/libe/caruana_en.pdf>; COPPENS, J., SOMERS, E., loc. cit., p. 380.
} 
by their own ports. ${ }^{53}$

In order to solve such problems and avoid the risk that commercial ships refrain from providing the due rescue or that warships have no other choice, due to diplomatic disagreement with the nearest states, than to conduct the migrants towards their own coasts, IMO adopted in 2004 some amendments to SOLAS and SAR Conventions, aimed at strengthening the search and rescue system and minimizing the inconveniences for ships carrying out an intervention. ${ }^{54}$

Article 4.1-1 SOLAS, as amended, states that:

"Contracting Governments shall co-ordinate and co-operate to ensure that masters of ships providing assistance by embarking persons in distress at sea are released from their obligations with minimum further deviation from the ships' intended voyage, provided that releasing the master of the ship from the obligations under the current regulation does not further endanger the safety of life at sea. The Contracting Government responsible for the search and rescue region in which such assistance is rendered shall exercise primary responsibility for ensuring such co-ordination and co-operation occurs, so that survivors assisted are disembarked from the assisting ship and delivered to a place of safety, taking into account the particular circumstances of the case and guidelines developed by the Organization. In these cases the relevant Contracting Governments shall arrange for such disembarkation to be effective as soon as reasonably practicable".

Article 3.1.9 SAR, as amended, is drafted in almost identical terms. ${ }^{55}$ Such amendments entered into force on 1 July 2006, according to the simplified revision mechanism of the mentioned conventions.

Problems have not disappeared, however: a relevant state like Malta did not accept the amendments, thus not being bound by them. Moreover, even under the amendments mentioned, the state responsible for the relevant SAR region does not seem to be under an unconditional duty to receive rescued persons: arguments have been put forward by some scholars in order to claim such duty in the event that no other state shows willingness to

\footnotetext{
${ }^{53}$ See the serious deficiencies in the behaviour of several military ships, emerged in the so called Strik Report: Parliamentary Assembly of the Council of Europe 2012, qtd. at $\S \S 141-149$; Parliamentary Assembly of the Council of Europe, Res. 1872 (2012), 24 April 2012.

${ }^{54}$ See IMO Maritime Safety Committee Resolutions MSC.153(78) and MSC.155(78), adopted on 20 May 2004.

55 "Parties shall co-ordinate and co-operate to ensure that masters of ships providing assistance by embarking persons in distress at sea are released from their obligations with minimum further deviation from the ships' intended voyage, provided that releasing the master of the ship from the obligations does not further endanger the safety of life at sea. The Party responsible for the search and rescue region in which such assistance is rendered shall exercise primary responsibility for ensuring such co-ordination and cooperation occurs, so that survivors assisted are disembarked from the assisting ship and delivered to a place of safety, taking into account the particular circumstances of the case and guidelines developed by the Organization. In these cases, the relevant Parties shall arrange for such disembarkation to be effective as soon as reasonably practicable."

The IMO Guidelines on the treatment of persons rescued at sea, adopted by Committee on Maritime Safety together with the mentioned amendments by Resolution MSC.167(78), defines place a safety a location where rescue operations are considered to terminate and that an assisting ship could only temporarily considered a place of safety (see $\S \S 6.12-6.14)$.
} 
accept disembarkation, ${ }^{56}$ but it must be admitted that the language of the 2004 amendments is carefully drafted in order to avoid any automatism ${ }^{57}$ and that it was chosen after lengthy and complex discussions in IMO quarters. ${ }^{58}$

It follows that this state of the art in international legislation must be read in conjunction with different interpretations of the SAR Convention by proximate Mediterranean countries. While Malta (which not by chance refused to accept the 2004 amendments) maintains that rescued persons must be disembarked at the closest safe port (usually at Lampedusa or in Sicily), ${ }^{59}$ Italy replies that unless a different arrangement is reached on a case-by-case basis, the state competent for the relevant SAR zone must allow the disembarkation: given the extension of the Maltese SAR area, this would mean La Valletta's port in the majority of cases. The dispute between these two countries - exacerbated by the subsequent duties to take charge of asylums seekers and of repatriation of migrants, absent a comprehensive and automatic EUbased mechanism of burden sharing - periodically produces relevant deadlocks, as illustrated by the following recent cases: the merchant ship Pinar (flying Panama's flag and whose owner had Turkish nationality), having rescued some migrants in Maltese SAR waters, was forced to wait for four days in the high seas, before being allowed by Italian authorities to approach Italian shores ${ }^{60}$; the Italian frigate Spica ${ }^{61}$ and the patrol boat Commander Borsini, ${ }^{62}$ which

\footnotetext{
${ }^{56}$ See TREVISANUT, S., loc. cit., 2010, p. 530. According to GAMMELTOFT-HANSEN, T., The Refugee, the Sovereign and the Sea: EU Interdiction Policies in the Mediterranean, DIIS Working Paper No. 2008/6, at pp. 25-27, the 2004 amendments oblige the State responsible for the relevant SAR zone to allow disembarkation. A similar stand seems proposed in the House of Lords European Union Committee's Ninth Report on the European Union, devoted to Frontex, 2008, § 109. A more nuanced position is expressed by WEINZIERL, R., LISSON, U., loc. cit., p. 40 (with further references).

${ }^{57}$ The language employed in the amendments would have been different if a strict duty to receive rescued persons were to be placed upon the said State. The failure to stipulate a precise State of disembarkation is not judged a defect per se by COPPENS, J., SOMERS, E., loc. cit., pp. 387-388, due to the need to take into account multiple factors in each situation, not least the different need of migrants in a context of mixed flows.

${ }^{58}$ For this view, see amongst others MALLIA, P., loc. cit., pp. 135-140; BARNES, R., loc. cit., pp. 139 and 142. See also UNHCR, Background Paper for the Expert Meeting in Djibouti, p. 3, n. 7.

${ }^{59}$ This was underlined by the Maltese Government with regard to some incidents occurring in the Libyan SAR region: see the letter of 8 June 2007 of the Malta Permanent Representative to the EU, addressed to the German Permanent Representative to the EU, in his capacity as Chairman of CoRePer, available at $<$ www. europarl.europa.eu/hearings/20070703/libe/caruana_en.pdf >; the statement of the Maltese Minister for justice and home affairs, delivered at the JHA Council meeting of 12 June 2007, available at <www.doi.gov.mt/en/ press_releases/2007/06/pr0870.asp>.

${ }^{60}$ As Italian authorities clearly stated, Italy permitted disembarkation solely in view of the serious humanitarian emergency occurred on board of the merchant ship, and this gesture must not be interpreted as a precedent, nor as a recognition of the reasons put forward by Malta in the subject-matter: see the joint press release of the Ministers of Foreign Affairs and of Home Affairs of 19 April 2009 <www.esteri.it/MAE/IT/Sala_Stampa/ArchivioNotizie/ Comunicati/2009/04/20090420_FrattiniMaroni_navePinar.htm?LANG=IT>. The Maltese Prime Minister, in a declaration released to his Parliament on 21 April 2009, underlined that the rescue occurred 41 nautical miles from Lampedusa and 114 nautical miles to the South West of Malta, thus rendering Italy the State responsible for accepting disembarkation <www.mfa.gov.mt/default.aspx?MDIS=21\&NWID=360>. See also the conclusions of the Maltese Council of Ministers of 5 May $2009<$ www.mfa.gov.mt/Default.aspx?MDIS=21\&NWID=378>.

${ }^{61}$ The facts occurred between 10 and 11 May 2009: see <www.timesofmalta.com/articles/view/20090511/ local/malta-rejects-new-italian-request-to-take-migrants $>$.

${ }^{62}$ The facts occurred between 13 and 14 August 2011: see<www.timesofmalta.com/articles/view/20110815/
} 
unsuccessfully tried to access La Valletta's port after having rescued a group of migrants in Maltese SAR waters and was later obliged to sail towards Port Empedocle in Sicily; the Liberian-flagged oil tanker Salamis, which refused to take to Libya the rescued migrants and after having tried to disembark them to its next port of call (La Valletta) and having received a strict refusal by Maltese authorities - was allowed to enter an Italian port on humanitarian grounds. ${ }^{63}$

This Italian-Maltese saga registered additional worrying developments. Following the occurrence of serious disorders in Lampedusa in the aftermath of the so-called Arab Springs, on 24 September 2011, the Italian authorities declared the island to be an 'unsafe port' under SAR Convention and related provisions,${ }^{64}$ realizing a sort of 'excision strategy' of the small island in the context of the controversial issue of the place of disembarkation ${ }^{65}$ and of the related identification of the closest safe port. On 1 October 2011, in a joint statement, UNHCR, IOM and Save the Children, part of the Praesidium project, ${ }^{66}$ warned that this decision would endanger rescue operations with coast guards unable to dock in Lampedusa, requiring them to travel further (supposedly up to Sicilian coasts or to Malta) to bring those rescued..$^{67}$ It must be admitted that the above-mentioned riots in Lampedusa (leading to the partial destruction of the centre of first accommodation of migrants, transformed into a sort of detention centre without access to judges, lawyers and asylum procedures) broke out because of the choice of the Italian authorities not to relocate in Sicily and on the mainland the thousands of persons who gradually had arrived on the small island from Tunisia and Libya during the previous weeks: the accumulation of persons in a precarious and uncertain situation on a small island (in a sort of no-law context) created strong tension with the authorities and, subsequently, even with the inhabitants. All these facts are not dependent on an objective inability of the Lampedusa island to receive persons rescued at sea, but are the consequences of an illconceived strategy of avoidance of responsibility by the Italian government in the context of migratory fluxes originated by the political changes in Northern Africa. The situation of Lampedusa was still unclear at the end of August 2013: rescued persons have been actually carried there by Italian public units following some SAR interventions on the high seas, but it seems that the declaration of 'unsafe port' has not yet been officially revoked.

local/Malta-refuses-migrants-rescued-by-Italian-ship.380260>.

${ }^{63}$ The facts occurred between 4 and 7 August 2013: see FRENZEN, N., op. cit.; <http://www.ilfattoquotidiano. it/2013/08/07/immigrazione-litalia-accogliera-nave-alla-quale-malta-ha-rifiutato-lingresso-in/678815>.

${ }^{64}$ See the information given by the Italian Government to the Chamber of Deputies on 28 September 2011, at $<$ www.camera.it $/ 410$ ?idSeduta $=0526 \&$ tipo $=$ stenografico\#sed0526.stenografico.tit00020 $>$.

${ }^{65}$ As a consequence, persons rescued at sea for whom Italy accepted responsibility were not brought to Lampedusa but to Sicily.

${ }^{66}$ On this Project, see UNHCR, Refugee Protection and International Migration: A Review of UNHCR'S Operational Role in Southern Italy, Doc. PDES/2009/05, September 2009 <www.unhcr.org/4ac35c600.pdf>; the press release on the UNHCR website $<$ www.unhcr.it/news/dir/168/praesidium.html $>$.

${ }^{67} \mathrm{See}<\mathrm{www} . u n h c r . i t / n e w s / d i r / 26 /$ view/1068/lampedusa-dichiarata-porto-non-sicuro-a-rischio-il-salvataggioin-mare-preoccupazione-per-la-prassi-del-trattenimento-dei-migranti-su-navi-106800.html>. 
Thus, differences among interested states about the identification of the place of safety may postpone the disembarkation and act as a disincentive for potential rescuing units. The state responsible for the SAR region - as a consequence of its inertia or of a limited will to fulfil its duty to handle the situation, owing to objective difficulties or opportunity considerations - may discharge upon other states and the intervening ship the burdens following a SAR activity. ${ }^{68}$ Here we are faced with a mix of legal and political issues: some years ago, it was rightly pointed out that the reluctance of EU Member States to provide patrol boats in the joint operations coordinated by Frontex was due to the risk that the country providing the boats would have remained responsible for migrants rescued or intercepted at sea ${ }^{69}$ Moreover, some ships might prefer not to fulfil their rescuing duties to avoid facing delays or costs arising from the uncertainties about disembarkation to a place of safety.

\section{THE FAILED ATTEMPT OF IMO AND EU TO ELABORATE NEW LEGAL STANDARDS}

Owing to the uncertainties discussed in the previous section, some initiatives have been taken by IMO bodies to overcome the difficulties. The Facilitation Committee, responsible for the implementation and updating of the Convention on Facilitation of International Maritime Traffic (FAL Convention), ${ }^{70}$ discussed the topic and approved in 2009 some interpretative guidelines of the 2005 amendments to the Convention, aimed at facilitating disembarkation of persons rescued at sea. A circular, of a recommendatory nature, containing "Principles relating to administrative procedures for disembarking persons rescued at sea" was adopted in January 2009, stating that

If disembarkation from the rescuing ship cannot be arranged swiftly elsewhere, the Government responsible for the SAR area should accept the disembarkation of the persons rescued in accordance with immigration laws and regulations of each Member State into a place of safety under its control in which the persons rescued can have timely access to post rescue support. $^{71}$

It is remarkable that several delegations opposed the use of the mandatory word 'shall' (originally present in the draft text) in recommendatory guidance, and accordingly the Committee agreed that 'shall' should be replaced by 'should', where it appeared. ${ }^{72}$ Besides, Japan (backed by many other states) required the insertion of the phrase "in accordance with

\footnotetext{
${ }^{68}$ A similar perplexity is expressed by MILTNER, B., loc. cit., p. 109.

${ }^{69}$ See LUTTERBECK, D., Coping With Europe's Boat People. Trends and Policy Dilemmas in Controlling the EU's Mediterranean Borders, ISPI Policy Brief No. $76<$ www.ispionline.it/it/documents/PB_76_2008.pdf >, February 2008, p. 5.

${ }^{70}$ Done at London, 9 April 1965, 115 Contracting States as of 31 January 2013.

${ }^{71}$ See Facilitation Committee, Principles Relating to Administrative Procedures for Disembarking Persons Rescued at Sea, Doc. FAL.3/Circ.194, 22 January 2009, § 2.3 (emphasis added).

${ }^{72}$ See Facilitation Committee, Report of the Facilitation Committee on Its Thirty-Fifth Session, Doc. FAL 35/17, 19 March 2009, § 6.59.
} 
immigration laws and regulation", thus further reducing the strength of the indication therein spelled. ${ }^{73}$ It must also be emphasized that strong objections were raised by some important IMO Member States (such as Australia, Malta and Spain), pointing either at the lack of competence of the FAL Committee on the subject matter ${ }^{74}$ or at the contrariness of such guidance to a proper interpretation of relevant provisions currently in force contained in the SAR and SOLAS Conventions as amended in 2004. ${ }^{75}$ In the light of the foregoing, it seems that this circular left the situation of uncertainty substantially unchanged.

In the same period, when the FAL Committee worked on the above-mentioned circular, in the framework of the activities of another IMO body, the Flag State Implementation (FSI) Sub-Committee, Spain and Italy jointly submitted a document ${ }^{76}$ proposing to adopt further amendments to SOLAS and SAR Conventions, in order to incorporate and even strengthen the solution put forward in the FAL Circular ${ }^{77}$ and thus to cast away any doubt about the identification of the state responsible for the disembarkation of the rescued individuals. Malta replied with articulate reasoning, claiming that already the 2004 amendments were excessively burdensome for the contracting state responsible for the relevant SAR region and that the right solution was for disembarkation to occur in the safe port closest to the location of the rescue. ${ }^{78}$ After a lengthy discussion, the FSI sub-committee recognized that the substance of the questions raised by Italy and Spain required an appropriate discussion in other IMO fora (the MSC [Maritime Safety Committee] and the COMSAR Sub-Committee). ${ }^{79}$ During the discussion in the COMSAR Sub-Committee held in March 2010, a wide majority of states did not support Italy and Spain's proposal to elaborate new amendments to SOLAS and SAR Conventions, emphasizing the satisfactory point of balance reached by the 2004 amendments and the need to solve outstanding problems in the context of the flexibility therein envisaged, thus calling for the conclusion among interested parties of dedicated regional or bilateral

\footnotetext{
${ }^{73}$ Ibid., $§ 6.58$.

${ }^{74}$ See Facilitation Committee, Report of the Facilitation Committee, qtd. at Ann. IV (Spain).

${ }^{75}$ Ibid., qtd. at p. 32, Ann. V (Australia), Ann. VI (Malta).

${ }^{76}$ See Doc. FSI/17/15/1, 13 February 2009, Compulsory Guidelines for the Treatment of Persons Rescued at Sea.

77 See the quoted document, $\S 10$. The proposed text of the amendment reads as follow: "The Contracting Government responsible for the search and rescue region, where the rescue operation takes place, shall exercise primary responsibility for ensuring that such coordination and co-operation occurs, so that the persons rescued at sea are disembarked from the vessel involved in the rescued operation and delivered to a place of safety under its control, where persons rescued at sea can have timely access to post rescue support" (emphasis added).

${ }^{78}$ See Doc. FSI 17/17/2, 27 February 2009, Comments on document 17/15/1, especially $\S \S 14-16$. It has been rightly observed that the Maltese position, though following a shareable approach in principle, appears to be pushed by its peculiar overreaching SAR zone, whose extension should instead be delimited according to the actual capacity of the concerned country to fulfil the correlated international obligations: see Trevisanut 2010, p. 532 .

${ }^{79}$ See Doc. FSI 17/20, 24 April 2009, Report to the Maritime Safety Committee and the Marine Environment Protection Committee, especially $\S \S 15.10-15.12$ (note that some delegations expressed their support to the proposal put forward by Italy and Spain).
} 
agreements. ${ }^{80}$

While in IMO the discussions were lively, even EU institutions were working on the subject of maritime operations and SAR events: as already mentioned, the EU Council adopted the Decision No. 2010/252, containing rules (in Part I) and recommendations (in Part II) supplementing the Schengen Borders Code as regards the surveillance of the sea external borders in the context of operational cooperation coordinated by Frontex. It must be taken into account that in any Frontex operation at sea, one Member State acts as host country. According to the recommendatory guidelines, the participating unit should forward as soon as possible all available information to the Rescue Coordination Centre responsible for the search and rescue region where the situation is taking place. In cases where the Rescue Coordination Centre of the third country responsible for the search and rescue region does not respond to the notification transmitted by the participating unit (as often occurred with Libya), the latter should contact the Rescue Coordination Centre of the host Member State. ${ }^{81}$ This solution has the merit of singling out a responsible authority in case of lack of cooperation by the competent third state, avoiding dangerous (negative) conflicts of competence among Member States.

Additionally, the recommendatory guidelines tackle the contentious issue of the place of disembarkation:

Without prejudice to the responsibility of the Rescue Coordination Centre, and unless otherwise specified in the operational plan, priority should be given to disembarkation in the third country from where the ship carrying the persons departed or through the territorial waters or search and rescue region of which that ship transited and if this is not possible, priority should be given to disembarkation in the host Member State unless it is necessary to act otherwise to ensure the safety of these persons. ${ }^{82}$

In the event of a scarce collaboration by third states of origin or transit, the burden of accepting disembarkation should lie on the host Member State. This choice presents its own intrinsic rationality, though not being the only conceivable, and it is open to different solutions to be specified in the operational plan of the mission.

Malta reacted very critically, announcing it would not host Frontex operations on its territory anymore. ${ }^{83}$ Later on, Malta expressed its readiness to host the 2010 Nautilus IV operation on condition that the operational plan specified that illegal immigrants rescued by the EU's sea patrols would be disembarked at the nearest safe port (i.e. very often Lampedusa

\footnotetext{
${ }^{80}$ See Doc. COMSAR 14/17, 19 March 2010, Report to the Maritime Safety Committee, $\S \S 10.14-10.17$.

${ }^{81}$ Part II, $\S 1.2$.

${ }^{82}$ Part II, § 2.1 (emphasis added). In similar terms, see doc. COM (2013) 197, qtd., under Article 10, §§ 3-4.

83 See <www.independent.com.mt/news.asp?newsitemid=103632>; <www.timesofmalta.com/articles/ view/20090426/local/rescued-immigrants-to-disembark-at-the-closest-safe-port>.
} 
or Sicily) $\cdot{ }^{84}$ It seems that the EU decision did not succeed in solving the outstanding issue of the choice of the place of disembarkation both in the case when two or more Member States are involved and in the limited case of a Frontex-led operation. The ball goes back into the IMO's field.

\section{NEW APPROACHES CURRENTLY UNDER STUDY BY THE IMO: TOWARDS A REGIONAL TREATY FOR THE MEDITERRANEAN SEA?}

Following a proposal put forward during the debate that took place in the 2010 COMSAR sub-committee, the IMO Secretary General offered his good offices for consultation among a group of interested states of the Mediterranean Basin. The MSC approved such an approach. ${ }^{85}$ One meeting was held in 2010, and two were held in the first half of 2011, in which Italy, Malta ${ }^{86}$ and Spain participated, during which it was agreed to develop a draft regional agreement on concerted procedures relating to the disembarkation of persons rescued at sea. The COMSAR Sub-Committee endorsed the proposal during its 2011 meeting and stated that such a regional agreement might serve as a 'pilot scheme,' which, if successful, could be extended to other parts of the world experiencing the same or similar situations. ${ }^{87}$

Moreover, during the 2011 meetings of this consultation group, it was agreed to expand the consultation to include other interested parties concerned (starting with Mediterranean countries) and relevant regional and international organizations, ${ }^{88}$ and that the first 'expanded' meeting would be held in Rome on 12 October $2011 .^{89}$ Subsequently, the IMO Secretariat was advised by the consultation group that the intention was to develop the regional agreement in the form of a Memorandum of Understanding $(\mathrm{MoU}) .^{90}$

The first regional meeting was attended by countries of the Mediterranean region (Algeria, Cyprus, France, Greece, Italy, Lebanon, Malta, Morocco, Spain, Turkey), by the United Kingdom and by the IMO Secretariat. The draft terms of reference were approved in principle, and a draft regional MoU was considered and partly revised during that meeting. In

\footnotetext{
${ }^{84}$ See $<$ www.independent.com.mt/news.asp?newsitemid=105294>.

${ }^{85}$ See Report of the Maritime Safety Committee on Its Eighty-Seventh Session, Doc. MSC 87/26, 25 May 2010, $\S \S 14.18-14.21$.

${ }^{86}$ Malta did not participate to the second meeting.

${ }^{87}$ See Doc. COMSAR 15/16, 29 March 2011, Report to the Maritime Safety Committee, $\S$ 10.10. See also the Report of the Legal Committee on the Work of Its Ninety-Eighth Session, Doc. LEG 98/14, 18 April 2011, § 13.25.

${ }^{88} \mathrm{See}$ the Note by the Secretariat on the progress made on the development of a draft Regional agreement on concerted procedures relating to the disembarkation of persons rescued at sea, Doc. MSC 89/INF.23, 12 April 2011.

${ }^{89}$ See the Note by the Secretariat on the progress made on the development of a draft Regional agreement on concerted procedures relating to the disembarkation of persons rescued at sea, Doc. FAL 37/6/1, 1 July 2011.

${ }^{90}$ See Doc. FAL 37/WP.1, 9 September 2011, § 6.32.
} 
order to make significant progress towards finalizing the draft regional MoU, it was considered beneficial to hold informal consultations among interested parties to agree on some of the more contentious issues and associated draft texts before organizing the next regional formal meeting. Accordingly, informal consultations of interested parties were held at IMO headquarters on 21 February 2012: some of the most contentious aspects were discussed and agreements reached on sensitive subjects, and the draft text of the regional MoU was improved accordingly. ${ }^{91}$

A second formal regional meeting, to review the draft $\mathrm{MoU}$, was planned to be held on 18 April 2012 at IMO Headquarters. ${ }^{92}$ However, during the 2013 COMSAR Sub-Committee session (held in January 2013), the Secretariat informed Member States that, following a request for more time to be given for informal consultations between some parties concerned, the meeting had been postponed and would be rescheduled in the near future. The sub-committee took note of this development and invited the MSC to extend the target completion year for this planned output to $2014 .{ }^{93}$ Bilateral consultations have continued in the last few months, and apparently some differences have been smoothed, but it is not still certain, at the moment of writing, when the regional meeting will be reconvened. ${ }^{94}$

\section{FINAL REMARKS}

Irregular migration by sea puts the search and rescue regime under high pressure. If some persistent ambiguity in the relevant provisions of SOLAS and SAR Conventions is a natural consequence of the need to take into account the peculiarities of the context, the high numbers of SAR operations (and of the related need to assume responsibilities for asylum seekers and irregular migrants) has exacerbated the matters of controversy, especially in the Mediterranean. IMO could reach a certain degree of consensus only on general rules and accompanying guidelines, but was unable to eliminate the ultimate grounds for divergence among its Member States: this is particularly evident in the tension between Italy and Malta. Nor has the EU been successful in drawing a precise line so far.

The reasons underlying the lack of adequacy of the current legal regime of SAR matters are grounded in other fields, i.e. the migratory policies and other priorities of some destination states, the issue of burden sharing among interested countries, the difficulty (both political and legal) of effectively dealing with some origin or transit states.

\footnotetext{
${ }^{91}$ See Doc. COMSAR 15/16, 29 March 2011, Report to the Maritime Safety Committee, $§ 10.3$.

${ }^{92}$ Invitation were extended to the Governments of Albania, Algeria, Bosnia and Herzegovina, Croatia, Cyprus, Egypt, France, Greece, Israel, Italy, Lebanon, Libya, Malta, Monaco, Montenegro, Morocco, Slovenia, Spain, the Syrian Arab Republic, Tunisia, Turkey and the United Kingdom.

${ }^{93}$ Information courteously provided by the IMO Secretariat on 25 February 2013.

${ }^{94}$ Information courteously provided by the Head of the Facilitation Section (Maritime Safety Division, IMO) and by the IMO External Relations Office on 27 February 2013 and on 10 July 2013.
} 
Certainly, promoting a cooperative approach tailored to the common problems affecting a given region - as IMO is trying to do with the Mediterranean states - appears to be a correct way to proceed. ${ }^{95}$ However, as underlined by UNHCR in some recent initiatives and positions, the connected problem of the responsibility for asylum seekers and refugees must be tackled as a matter of priority ${ }^{96}$; to this end, the issues posed by irregular migrants and by their eventual repatriation must also be matched, not leaving alone the states more exposed to incoming flows.

Towards this end, I think that a crucial role in the Mediterranean should be played by the EU and its Member States, taking into account that the main problems at stake concern or involve them in a substantial way. A more effective system of burden sharing ${ }^{97}$ among EU Member States could pave the way for fruitful talks about the disembarkation procedures and the delimitation of SAR zones (both among EU Member States and between them and third states, in the framework of the process sponsored by IMO), obliging the interested actors to take more transparent and verifiable stances.

Additionally, a cohesive EU would be stronger and more credible interacting with transit countries and origin countries on the complex issues raised by international migration. In such a perspective, addressing some root causes and proposing a truly global approach might help in reducing irregular flows and the related worrying negative side effects on the human rights of migrants. It is time to abandon the idea that challenges raised by irregular migratory movements may be faced only (or almost exclusively) with repressive instruments or securitybased preventive tactics. Equally, it must be clear that cooperative deals may not be made with whatsoever state, no matter how decisive its support may be for contrasting smugglers ${ }^{98}$ : human rights come first, as authoritatively asserted by the European Court of Human Rights in the recent Hirsi judgment.

\footnotetext{
${ }^{95}$ To this views, see also TREIVISANUT, S., loc. cit., 2010, pp. 525-526 and 538-539.

${ }^{96}$ UNHCR, Summary Conclusions of the Expert Meeting in Djibouti (8-10 November 2011). Refugees and Asylum-Seekers in Distress at Sea - How Best to Respond?, 5 December 2011, §§ 22-23 (and the annexed Model Framework for Cooperation following rescue at sea operations involving asylum-seekers and refugees); Background Paper, qtd.

${ }^{97}$ A system of burden sharing undoubtedly must include the vexed question of the relocation of asylum seekers and refugees (a sort of taboo so far for many EU Member States, firmly opposing any preventive legal engagement), but should also embrace enhanced forms of support, to be built upon existing tools such as RAPID and EASO expert teams, and upon good practices like the Praesidium Project. See also the idea of setting up 'Mobile Protection Response Teams', advanced by the UNHCR, Background Paper, ANN, B; Summary Conclusions of the Expert Meeting in Djibouti, $\S$ 20-21.

${ }_{98}$ See the discussion on the concept of "place of safety", supra $\S 4$.
} 


\section{ADDENDUM}

This article was completed in late August 2013, some weeks before the outcry caused by a tragic incident occurred near the shores of Lampedusa on $3^{\text {rd }}$ of October, leading to the death of at least 366 persons in just one night. Apart from the condolences and the onthe-spot declarations released by many politicians (both of European States and of the EU itself), no change of perspective has been pushed ahead. Again, a security-based approach seems to be preferred again and again, with the reinforcement of control devices (such as Frontex and Eurosur) which will probably lead smugglers to opt for even more dangerous or degrading techniques to circumvent the controls and allow migrants to reach the European "promised land". Only in part, the issue of a more balanced burden sharing seems to have gained momentum in European circles, following a strong call coming from the Italian government: anyway, precise legal provisions and political orientations are still lacking and further substantial discussions are postponed to the meeting of the European Council of June 2014.

In the meanwhile, the ongoing discussion on the new regulation on the Frontex-led operations at sea records a worrying aptitude by six EU Mediterranean States (Cyprus, France, Greece, Italy, Malta, and Spain): those States formalized in a joint document (No. 14612/13 of 10 Oct. 2013) their strong opposition to Articles 9 and 10 of the draft proposal of the Commission. They underlined the lack of competence of the EU to legislate on SAR matters, the presence of an extensive regulation at international level and the risk to create legal confusion (sic.), and, in any case, the sufficiency of a quick reference to applicable international law and to supplementary arrangements to be included each time in the relevant operational plan. At the time of writing, a compromise proposal was advanced by the Council Presidency in document No. 16825/13 of 27 Nov. 2013. 


\section{PAIX ET SÉCURITÉ INTERNATIONALES}

REVUE MAROCCO-ESPAGNOLE DE DROIT INTERNATIONAL ET RELATIONES INTERNATIONALES

NOUVELLE ÉPOQUE

SUMARIE / Janvier - Décembre 2013 / N 1

\section{ÉDITORIAL}

Rachid el Houdaïgui, Alejandro del Valle Gálvez y Miguel Acosta Sánchez

\section{ÉTUDES}

José Manuel SOBRINO HEREDIA

La politique maritime integré de la UE et les bassins maritimes européens

Antonio BLANC ALTEMIR, Bénédicte REAL

Un nouevel élan dans les relations euro-méditerranéennes

Marcello DI FLLIPPO

Irregular Migration across the Mediterranean Sea: Problematic Issues Concerning the International Rules on

Safeguard of Life at Sea

\section{Zakaria ABOUDDAHAB}

La participation du Maroc au Partenariat de Deauville sur fond the transition dans les pays arabes

Irene FERNÁNDEZ MOLINA, Miguel HERNANDO DE LARRAMENDI

La construction de la interdépendance entre l'Espagne et le Maroc (1995-2009)

Victor L. GUTIIÉRREZ CASTILLO, Juan J. GARCÍA BLESA

Le Détroit de Gibraltar et l'application de la normative de l'Union Europeenne relativa aux énergies renovables

Mohamed ALI TOUZI

La vision de la Méditerranée depues les deux rives: una perpective a débatre

\section{NOTES}

Jean DUFOURCQ

Vers un espace stratégique euromahrébin

Nora SEDDEKI

Place du droit international dans le système juridique des Etats

Carlos ECHEVERRÍA JESÚS

Kidnappings as a terrorist instrument of AIQM and the MUJAO

Youssef EL HAMDOUNI

Internet y la Primavera Árabe: hacia una nueva percepción del ciberespacio

\section{DOCUMENTATION}

